
VOLUME 10 NOMOR 6 DESEMBER 2021

ISSN : 2303-1514 | E-ISSN : 2598-5949

\title{
ANALISIS KETERLIBATAN ORANG TUA TERHADAP KEDISIPLINAN BELAJAR SISWA KELAS 2 SEKOLAH DASAR
}

\author{
Laily Nurmalia ${ }^{1}$, Melly Admelia ${ }^{2}$, Nabila Farhana ${ }^{3}$, Koyimah $^{4}$ \\ 1,2,3 Universitas Muhammadiyah Jakarta, Tangerang Selatan, Indonesia \\ ${ }^{4}$ SD Al Ikhwan, Tangerang Selatan, Indonesia \\ ${ }^{1}$ laily.nurmalia@gmail.com ${ }^{2}$ mellyadmelia07@gmail.com ${ }^{3}$ nabilafar.nf@gmail.com ${ }^{4}$ koyimah0812@gmail.com
}

\section{ANALYZING PARENTS' INVOLVEMENT IN STUDENTS' LEARNING DISCIPLINE AT GRADE 2 ELEMENTARY SCHOOL}

\section{ARTICLE HISTORY}

Submitted:

11 Oktober 2021

$11^{\text {th }}$ October 2021

Accepted:

28 November 2021

$28^{\text {th }}$ November 2021

Published:

27 Desember 2021

$27^{\text {th }}$ December 2021

\section{ABSTRACT}

Abstract: The purpose of this study was to analyze the involvement of parents in the learning discipline of grade 2 elementary school students. This study used a qualitative method with a case study approach. Based on the results of research and data analysis obtained from observations and interviews with class teachers, parents, and students, it was concluded that some students still lacked discipline in learning, especially in the aspect of collecting assignments. This was due to the busy work experienced by the parents of these students, which caused a lack of parents' involvement in accompanying children to study. As a result, students were often late in collecting assignments that the teacher gave. The participation of parents in the child's learning process meant to involve themselves in helping and assisting children in doing school assignments. Elementary school-age children still needed assistance from others, especially from parents, in carrying out the learning process to support the success of the child's education process, especially in child behavior development. One aspect of children's behavior development that needed to be considered was discipline. One of the aspects of students' learning discipline was collecting assignments based on the time determined by the teacher and is responsible for doing the tasks given by the teacher. Learning discipline had several factors, one of which was external factors coming from the family environment.

Keywords: parents' involvement, learning discipline, students

Abstrak: Tujuan penelitian ini adalah untuk menganalisis mengenai keterlibatan orang tua terhadap kedisiplinan belajar siswa kelas 2 sekolah dasar. Penelitian ini menggunakan metode kualitatif dengan pendekatan studi kasus. Berdasarkan hasil penelitian dan analisis data yang diperoleh dari hasil observasi dan wawacara kepada guru kelas, orang tua siswa, dan siswa maka dapat diperoleh kesimpulan bahwa terdapat siswa yang masih kurang memiliki sikap kedisiplinan dalam belajar terutama dalam aspek pengumpulan tugas. Hal tersebut disebabkan oleh kesibukan perkerjaan yang dialami orang tua dari siswa tersebut yang menyebabkan kurangnya keterlibatan orang tua dalam mendampingi anak belajar, sehingga siswa sering kali terlambat dalam mengumpulkan tugas yang sudah diberikan oleh guru. Keterlibatan orang tua dalam proses pembelajaran anak adalah melibatkan diri dalam membantu dan mendampingi anak mengerjakan tugas-tugas sekolah yang telah diberikan. Anak usia sekolah dasar masih sangat membutuhkan pendampingan dari orang lain terutama dari orang tua dalam melaksanakan proses pembelajaran untuk membantu keberhasilan proses pendidikan anak terutama dalam aspek perkembangan perilaku anak. Salah satu aspek perkembangan perilaku anak yang perlu untuk diperhatikan yaitu sikap disiplin. Aspek kedisiplinan belajar siswa salah satunya yaitu mengumpulkan tugas sesuai dengan waktu yang ditentukan oleh guru, serta bertanggung jawab mengerjakan tugas yang telah diberikan oleh guru. Kedisiplinan belajar memiliki beberapa faktor salah satunya yaitu faktor eksternal yang berasal dari lingkungan keluarga.

Kata Kunci: keterlibatan orang tua, kedisiplinan belajar, siswa

\section{CITATION}

Nurmalia, L., Admelia, M., Farhana, N., \& Koyimah, K. (2021). Analisis Keterlibatan Orang Tua Terhadap Kedisiplinan Belajar Siswa Kelas 2 Sekolah Dasar. Primary: Jurnal Pendidikan Guru Sekolah Dasar, 10 (6), 1654-1663. DOI: http://dx.doi.org/10.33578/jpfkip.v10i6.8555. 


\section{PENDAHULUAN}

Pendidikan merupakan suatu usaha seseorang untuk mengembangkan kemampuan yang ada pada diri seseorang, dengan demikian seseorang sangat membutuhkan pendidikan untuk keberlangsungan hidupnya (Taufiq, Prianto, \& Mikarsa, 2014). Menurut peneliti dengan melihat keadaan pendidikan yang ada di sekitar pentingnya pendidikan ini harus mendapatkan banyak perhatian dari berbagai pihak di antaranya adalah pemerintah, masyarakat, sekolah, dan juga keluarga. Perhatian yang sangat mendasar dari keempat pihak yaitu berasal dari perhatian keluarga, karena keluarga merupakan faktor utama dan mendasar bagi anak dalam mendapatkan pendidikan sebelum ke lingkungan masyarakat dan sekolah.

Keluarga merupakan lembaga pendidikan yang pertama dan utama. Keluarga memiliki hak untuk memberikan pendidikan anak di dalam rumah, di sekolah, dan di masyarakat dengan tujuan untuk keberhasilan akademis anak (Yulianingsih, Suhanadji, Nugroho, \& Mustakim, 2020). Orang tua dalam pendidikan di keluarga memiliki peranan penting, apalagi selama belajar dari rumah. Peran orang tua dalam kegiatan pembelajaran dari rumah adalah sebagai pendamping, karena orang tua lah yang berinteraksi langsung dengan anak di rumah.

Keterlibatan orang tua dalam pendidikan anak tidak hanya sebatas menanggung keperluan materi saja tetapi dalam pendidikan keteribatan orang tua harus satu lingkup lebih luas, seperti menjadi pendidik, pendamping, pembimbing, dan pengamat proses pembelajaran. Keterlibatan orang tua berperan penting dalam pendidikan, karena keterlibatan orang tua berdampak terhadap perkembangan anak dalam berbagai aspek kecerdasan pada anak, salah satunya adalah aspek afektif berupa kedisiplinan anak. Menurut Andersen (Saftari \& Fajriah, 2019) aspek afektif merupakan aspek yang memiliki keterkaitan dengan hal yang bersifat emosional seperti perasaan, minat, sikap, serta kepatuhan terhadap moral. Aspek afektif meliputi tanggung jawab, kerjasama, disiplin, komitmen, percaya diri, jujur, menghargai pendapat orang lain, serta kemampuan dalam mengendalikan diri.

Salah satu aspek afektif yang penting untuk diperhatikan yaitu adalah sikap disiplin. Menurut Fitria (Ansel \& Pawe, 2021) disiplin merupakan sikap yang dilakukan secara sadar oleh seseorang dalam mengikuti dan menaati peraturan-peraturan, nilai-nilai, serta hukum yang berlaku pada suatu lingkungan tertentu. Menurut Sugiarto (Arumingtyas, 2021) sikap disiplin sangat diperlukan dalam proses pembelajaran karena sikap disiplin dalam belajar merupakan kunci keberhasilan pada kegiatan pembelajaran. Sikap disiplin dalam proses pembelajaran berkaitan erat dengan kedisiplinan belajar. Kedisiplinan belajar merupakan ketatan dan kepatuhan yang dilakukan oleh siswa yang berkaitan dengan perubahan tingkah laku dan sikap dalam menaati peraturan yang diperoleh melalui latihan atau pengalaman siswa selama mengikuti proses pembelajaran di sekolah (Akmaluddin \& Haqiqi, 2019).

Bentuk kedisiplinan belajar yang harus dilakukan oleh siswa di sekolah yaitu mengikuti pembelajaran dengan baik, melakukan presensi tepat waktu, memperhatikan penjelasan dari guru, serta bertanggung jawab untuk mengerjakan dan menyelesaikan tugas-tugas yang diberikan oleh guru dengan tepat waktu (Arumingtyas, 2021). Kedisiplinan belajar memiliki beberapa faktor yang mempengaruhinya, di antaranya yaitu faktor internal dan faktor eksternal. Faktor internal merupakan faktor yang terdapat dalam diri seseorang yang meliputi kesadaran diri, motivasi belajar, dan tidak mampu menyesuaikan diri dalam belajar. Sedangkan faktor eksternal merupakan faktor yang berasal dari luar diri seseorang yang meliputi faktor 
keluarga, teman sebaya, lingkungan sekolah, dan masyarakat (Sugiarto, Suyati, \& Yulianti, 2019). Salah satu faktor eksternal yang mempengaruhi kedisiplinan belajar adalah faktor keluarga. Keterlibatan orang tua merupakan salah satu faktor keluarga yang mempengaruhi kedisiplinan belajar.

Anak usia sekolah dasar masih belum mampu belajar mandiri tanpa adanya pendampingan dari orang tua (Efendi, 2020). Anak usia sekolah dasar masih sangat memerlukan bantuan dan perhatian khusus dari orang lain baik dari orang tua di rumah maupun dari guru di sekolah dalam proses pembelajaran. Orang tua harus berusaha untuk meluangkan waktunya untuk mendampingi anak belajar agar proses pembelajaran dapat berjalan dengan baik. Oleh karena itu keterlibatan orang tua sangat penting dan sangat diperlukan dalam mendampingi anak belajar terutama mendampingi anak dalam mengerjakan dan menyelesaikan tugas yang diberikan oleh guru dengan tepat waktu.

Berdasarkan hasil pengamatan pada siswa kelas 2 di Sekolah Dasar X terdapat siswa yang kurang memiliki sikap kedisiplinan dalam belajar terutama dalam aspek pengumpulan tugas. Hal tersebut disebabkan oleh kesibukan perkerjaan yang dialami orang tua dari siswa tersebut yang menyebabkan kurangnya keterlibatan orang tua dalam mendampingi anak belajar, sehingga siswa seringkali terlambat dalam mengumpulkan tugas yang sudah diberikan oleh guru.

Berdasarkan latar belakang tersebut, tujuan penelitian ini adalah untuk menganalisis mengenai keterlibatan orang tua terhadap kedisiplinan belajar, sehingga peneliti tertarik membuat penelitian yang berjudul analisis keterlibatan orang tua terhadap kedisiplinan belajar siswa kelas 2 di Sekolah Dasar X.

\section{KAJIAN TEORI}

Keterlibatan orang tua sangat perlu untuk diterapkan dalam mendampingi anak belajar karena keterlibatan orang tua dapat memberikan pengaruh terhadap keberhasilan anak dalam belajar di sekolah. Keterlibatan orang tua juga dapat menjadi sarana untuk meningkatkan kerjasama antara pendidik di sekolah dan peran orang tua di rumah.

Menurut Ntekane (Sopiah, 2020) keterlibatan orang tua merupakan suatu kondisi di mana orang tua secara langsung terlibat dalam proses pendidikan anak-anak mereka, seperti memastikan untuk membantu anak dalam proses pembelajaran selayaknya tugas mereka sebagai orang tua di rumah. Keterlibatan orang tua menurut Hornby (Diadha, 2015) merupakan sebuah partisipasi yang dilakukan oleh orang tua dalam melaksanakan proses pendidikan dan pengalaman bagi anak-anak mereka.

Keterlibatan orang tua dalam pendidikan juga termasuk ke dalam kehadiran orang tua dalam mendampingi dan juga turut serta mengalami proses belajar yang diikuti oleh anak. Sedangkan menurut Patmadewo (Yulianingsih et al., 2020) keterlibatan orang tua adalah suatu proses yang dilakukan oleh orang tua terhadap keperluan diri sendiri, anak, serta program yang dilakukan oleh anak.

Berdasarkan pendapat yang sudah dijabarkan oleh para ahli di atas, maka pengertian dari keterlibatan orang tua dapat didefinisikan sebagai suatu tindakan yang dilakukan oleh orang tua sebagai partisipasinya dalam mendampingi dan melibatkan dirinya dalam proses pembelajaran anak secara langsung.

Menurut Altschul (Kristiyani, 2016) keterlibatan orang tua memiliki beberapa komponen-komponen di antaranya yaitu, (1) behavioral, komponen behavioral meliputi berkomunikasi dengan guru, menghadiri kegiatan sekolah, terlibat dalam organisasi sekolah, serta membangun hubungan dengan komunitas yang ada di sekolah; (2) cognitiveintellectual, komponen ini meliputi penyediaan materi-materi pendukung belajar, terlibat dalam pengerjaan PR, mendiskusikan materi pelajaran di rumah, membantu anak membuat keputusan, serta berdiskusi mengenai pendidikan dengan anak; (3) personal, 
komponen personal meliputi menjalin interaksi emoisonal, terlibat dalam kegiatan rekreatif dengan anak, mengasuh anak, serta membangun komunikasi yang baik dengan anak.

Schunk, Pintrich, \& Meece (Kristiyani, 2016) mengemukakan bahwa keterlibatan orang tua dalam pendidikan anaknya memiliki beberapa bentuk di antaranya adalah dengan melibatkan diri dalam membantu dan mendampingi anak mengerjakan tugas-tugas sekolah yang telah diberikan oleh guru, terlibat dalam kegiatan-kegiatan di sekolah, memberikan sumber-sumber pendukung belajar anak, bertemu dengan guru di kelas anaknya, mendatangi sekolah anaknya, membantu anak saat memilih program tambahan pelajaran, mengamati perkembangan anak, serta memberikan nilai-nilai pendidikan pada anak. Sedangkan menurut Park dkk. (Diadha, 2015) keterlibatan orang tua memiliki hubungan terhadap ketercapaian tugas-tugas anak serta perkembangan anak baik dalam aspek kognitif maupun aspek perkembangan lainnya.

Keterlibatan orang tua dalam proses pembelajaran sangat diperlukan pada setiap jenjang pendidikan, terutama pada anak usia sekolah dasar. Anak usia sekolah dasar masih belum mampu belajar mandiri tanpa adanya pendampingan dari orang tua (Efendi, 2020). Anak usia sekolah dasar masih sangat memerlukan bantuan dan perhatian khusus dari orang lain baik dari orang tua di rumah maupun dari guru di sekolah dalam proses pembelajaran. Orang tua harus berusaha untuk meluangkan waktunya dalam mendampingi anak belajar agar proses pembelajaran dapat berjalan dengan baik. Sedangkan menurut (Damsy et al, 2020) anak usia sekolah dasar dalam perkembangannya masih membutuhkan bantuan dari orang lain terutama dari pihak keluarga, orang tua memiliki peranan yang sangat diperlukan dalam membantu keberhasilan proses pendidikan anak terutama pada aspek perkembangan perilaku anak.

Berdasarkan pendapat para ahli di atas dapat disimpulkan bahwa anak usia sekolah dasar masih sangat membutuhkan pendampingan dari orang lain terutama dari orang tua dalam melaksanakan proses pembelajaran untuk membantu keberhasilan proses pendidikan anak terutama dalam aspek perkembangan perilaku anak.

Aspek perkembangan perilaku anak termasuk ke dalam aspek afektif dalam proses pembelajaran. Menurut Andersen (Saftari \& Fajriah, 2019) aspek afektif merupakan aspek yang memiliki keterkaitan dengan hal yang bersifat emosional seperti perasaan, minat, sikap, serta kepatuhan terhadap moral. Aspek afektif meliputi tanggung jawab, kerjasama, disiplin, komitmen, percaya diri, jujur, menghargai pendapat orang lain, serta kemampuan dalam mengendalikan diri. Salah satu aspek perkembangan perilaku anak yang perlu untuk diperhatikan yaitu sikap disiplin.

Menurut Fitria (Ansel \& Pawe, 2021) disiplin merupakan sikap yang dilakukan secara sadar oleh seseorang dalam mengikuti dan menaati peraturan-peraturan, nilai-nilai, serta hukum yang berlaku pada suatu lingkungan tertentu. Disiplin menurut Mustari (Akmaluddin \& Haqiqi, 2019) merupakan suatu sikap yang memperlihatkan perilaku tertib dan patuh terhadap semua ketentuan dan peraturan yang berlaku. Berdasarkan pendapat para ahli di atas dapat disimpulkan bahwa disiplin merupakan suatu sikap yang dilakukan oleh seseorang dalam menaati dan mematuhi peraturan yang berlaku pada suatu lingkungan tertentu baik peraturan yang tertulis maupun peraturan tidak tertulis.

Menurut Sugiarto (Arumingtyas, 2021) sikap disiplin sangat diperlukan dalam proses pembelajaran karena sikap disiplin dalam belajar merupakan kunci keberhasilan pada kegiatan pembelajaran. Sikap disiplin dalam proses pembelajaran berkaitan erat dengan kedisiplinan belajar. Kedisiplinan belajar merupakan ketaatan dan kepatuhan yang dilakukan oleh siswa yang berkaitan dengan perubahan tingkah laku dan sikap dalam menaati peraturan yang diperoleh 
melalui latihan atau pengalaman siswa selama mengikuti proses pembelajaran di sekolah (Akmaluddin \& Haqiqi, 2019).

Kedisiplinan belajar menurut Gunarsa (Sugiarto et al., 2019) adalah suatu kepatuhan dan ketaatan terhadap peraturan baik secara tertulis maupun tidak tertulis yang berkaitan dengan proses perubahan perilaku yang terjadi berdasarkan pengalaman mengamati, membaca, menirukan, mencoba sesuatu, mendengarkan, serta mengikuti arahan.

Berdasarkan beberapa pendapat para ahli di atas dapat disimpulkan bahwa kedisiplinan belajar merupakan suatu ketaatan dan kepatuhan terhadap peraturan baik secara tertulis maupun secara tidak tertulis yang berkaitan dengan proes berubahan perilaku siswa selama mengikuti pembelajaran di sekolah.

Bentuk kedisiplinan belajar yang harus dilakukan oleh siswa di sekolah yaitu mengikuti pembelajaran dengan baik, melakukan presensi tepat waktu, memperhatikan penjelasan dari guru, serta bertanggung jawab untuk mengerjakan dan menyelesaikan tugas-tugas yang diberikan oleh guru dengan tepat waktu (Arumingtyas, 2021).

Sedangkan menurut menurut Tu'u (Puspitasari \& Sutriyono, 2018) terdapat 3 bagian aspek dengan indikator disiplin belajar yang meliputi: (1) Kepatuhan mengikuti proses belajar mengajar dengan indikator, a) mendengarkan guru ketika proses pembelajaran berlangsung dan memanfaatkan waktu dengan baik saat guru memberikan materi, b) tidak meninggalkan kelas ketika proses pembelajaran berlangsung dan bertanggung jawab dalam mengerjakan tugas dengan baik penuh kedisiplinan seperti mengumpulkan tugas sesuai dengan waktu yang ditentukan oleh guru, serta juga bertanggung jawab terhadap tugas yang dikerjakan. (2) Kepatuhan pada tata tertib sekolah dengan indikator, a) hadir ke sekolah dengan tepat waktu sesuai dengan waktu yang telah ditentukan oleh sekolah, b) menaati peraturan dan tata tertib yang telah dibuat oleh sekolah, c) bersikap santun dan hormat pada warga sekolah. (3) Ketaatan pada jam belajar dengan indikator, a) membuat jadwal pembelajaran dengan rutin agar disiplin dalam belajar, b) menggunakan waktu belajar dengan efektif, dan c) tidak menunda-nunda dalam menyelesaikan tugas pekerjaan rumah yang diberikan oleh guru.

Berdasarkan beberapa pendapat para ahli di atas mengenai aspek-aspek kedisiplinan belajar, dapat disimpulkan bahwa salah satu aspek kedisiplinan belajar yaitu, bertanggung jawab dalam mengerjakan tugas dengan baik penuh kedisiplinan seperti mengumpulkan tugas sesuai dengan waktu yang ditentukan oleh guru, serta juga bertanggung jawab mengerjakan tugas yang telah diberikan oleh guru.

Kedisiplinan yang dimiliki setiap inidvidu akan berbeda-beda, terutama pada siswa, ada siswa yang memiliki kedisiplinan tinggi dan ada siswa yang memiliki kedisiplinan yang rendah. Menurut Amri (Kaminudin Telaumbanua, 2018) tinggi dan rendahnya tingkatan kedisiplinan pada individu dipengaruhi oleh beberapa faktor baik dari faktor luar maupun faktor luar.

Menurut Yuliantika dalam penelitiannya (Lestari, Murtono, \& Purbasari, 2021) faktor yang mempengaruhi kedisiplinan belajar pada siswa ada dua faktor, faktor yang pertama yaitu faktor internal yang berasal dari dalam diri siswa serta faktor eksternal yaitu faktor yang berasal dari luar, yang terdapat dari kebiasaan orang tua, penetapan kebijakan seperti tata tertib sekolah, dan kondisi dalam masyarakat.

Faktor-faktor yang mempengaruhi kedisiplinan siswa, yaitu 1) anak itu sendiri, dalam menanamkan sikap disiplin pada anak harus terus diperhatikan setiap pribadi dari anak tersebut, karena akan berpengaruh terhadap keberhasilan penanaman kedisiplinan, 2) sikap guru, penanaman kedisiplinan pada anak akan berhasil jika dipengaruhi oleh sikap guru yang baik dan memberikan kasih sayang akan sangat berpengaruh untuk menanamkan 
sikap disiplin pada anak, 3) lingkungan juga merupakan faktor yang mempengaruhi kedisiplinan pada anak, khususnya kondisi dan situasi lingkungan sekolah, lingkungan keluarga, dan lingkungan maskarakat baik lingkungan teknis maupun sosiokultural, 4) faktor yang keempat ini yaitu faktor tujuan dalam penanaman kedisiplinan (Kaminudin Telaumbanua, 2018).

Berdasarkan uraian mengenai faktorfaktor yang mempengaruhi kedisiplinan siswa dalam belajar dapat disimpulkan bahwa ada dua yaitu faktor internal dan faktor eksternal. Faktor internal yaitu faktor yang berasal dari diri siswa seperti motivasi, minat bakat, kemampuan siswa, dan juga konsentrasi siswa, sedangkan faktor eksternal atau ekstrinsik yaitu faktor yang berasal dari lingkungan yaitu seperti lingkungan keluarga, sekolah, dan masyarakat.

\section{METODE PENELITIAN}

Penelitian ini dilakukan pada saat peneliti melakukan praktik Pengenalan Lapangan Persekolahan (PLP) di salah satu Sekolah Dasar X di Tangerang Selatan. Penelitian ini dilaksanakan pada semester tujuh (ganjil) mulai dari bulan Agustus 2021 sampai dengan Oktober 2021.

Penelitian ini menggunakan metode kualitatif, dengan pendekatan studi kasus dan dengan subjek yaitu satu orang siswa $X$, guru kelas, dan juga orang tua siswa X. Teknik pengumpulan data pada penelitian ini menggunakan studi pustaka dengan mengkaji jurnal sebagai sumber yang berkaitan dengan objek penelitian sebagai bahan teoritis dan juga penelitian secara langsung dengan melakukan kegiatan observasi dan wawancara.

Teknik analisis data pada penelitian ini dikerjakan secara kualitatif. Teknik analisis data dilakukan dengan melakukan observasi lalu melakukan wawancara terhadap subjek yaitu siswa X kelas $2 \mathrm{SD}$, Guru kelas $2 \mathrm{SD}$, dan orang tua siswa $X$ selama proses penelitian berlangsung.

Tabel 1. Kisi-Kisi Instrumen Wawancara Guru Kelas

\begin{tabular}{ccll}
\hline No. & \multicolumn{1}{c}{ Aspek } & \multicolumn{1}{c}{ Indikator } & Pertanyaan \\
\hline & & Mengetahui ketepatan waktu siswa & \\
1. & Ketepatan Waktu & dalam pengumpulan tugas sesuai dengan & 2 Pertanyaan \\
& & waktu yang telah ditentukan oleh guru. & \\
& & Mengetahui tanggung jawab siswa & 2 Pertanyaan \\
& terhadap tugas yang yang telah & \\
& diberikan oleh guru. & \\
2. Tanggung Jawab & Mengetahui konsekuensi yang terjadi & \\
& & apabila siswa tidak memiliki tanggung & 1 Pertanyaan \\
& jawab terhadap tugas yang diberikan. & \\
\hline
\end{tabular}

Tabel 2 . Kisi-Kisi Instrumen Wawancara Orang Tua

\begin{tabular}{cclc}
\hline No. & \multicolumn{1}{c}{ Aspek } & \multicolumn{1}{c}{ Indikator } & Pertanyaan \\
\hline 1. & Ketepatan Waktu & $\begin{array}{l}\text { Mengetahui ketepatan waktu siswa dalam } \\
\text { pengumpulan tugas sesuai dengan waktu } \\
\text { yang telah ditentukan oleh guru. } \\
\text { Mengetahui tanggung jawab siswa } \\
\text { terhadap tugas yang yang telah diberikan } \\
\text { oleh guru. } \\
\text { 2. Tengetahui keterlibatan orang tua dalam } \\
\text { membantu dan mendampingi anak } \\
\text { mengerjakan tugas-tugas sekolah yang } \\
\text { telah diberikan. }\end{array}$ & 2 Pertanyaan \\
3. & Keterlibatan & Orang Tua &
\end{tabular}



VOLUME 10 NOMOR 6 DESEMBER 2021

ISSN : 2303-1514 | E-ISSN : 2598-5949

Tabel 3. Kisi-Kisi Instrumen Wawancara Siswa

\begin{tabular}{llll}
\hline No. & \multicolumn{1}{c}{ Aspek } & \multicolumn{1}{c}{ Indikator } & Pertanyaan \\
\hline 1. & Ketepatan Waktu & $\begin{array}{l}\text { Mengetahui ketepatan waktu siswa } \\
\text { dalam pengumpulan tugas sesuai dengan } \\
\text { waktu yang telah ditentukan oleh guru. } \\
\text { Mengetahui tanggung jawab siswa } \\
\text { terhadap tugas yang yang telah diberikan } \\
\text { oleh guru. }\end{array}$ & 2 Pertanyaan \\
& Tanggung Jawab & $\begin{array}{l}\text { Mengetahui keterlibatan orang tua dalam } \\
\text { membantu dan mendampingi anak } \\
\text { mengerjakan tugas-tugas sekolah yang } \\
\text { telah diberikan. }\end{array}$ & \\
3. & Keterlibatan & &
\end{tabular}

\section{HASIL DAN PEMBAHASAN}

Penelitian ini menggunakan teknik observasi dan wawancara untuk memperoleh data mengenai keterlibatan orang tua terhadap kedisiplinan siswa. Peneliti melakukan observasi selama proses pembelajaran di kelas 2 Sekolah Dasar Al Ikhwan Pondok Aren dan memperoleh 1 subjek yaitu siswa $X$ yang memiliki permasalahan terhadap kedisiplinan belajar. Peneliti melakukan wawancara kepada
3 subjek, yaitu guru kelas, orang tua siswa, serta siswa yang ingin diteliti dengan mengajukan 5 pertanyaan yang berkaitan dengan aspek ketepatan waktu pengumpulan tugas, tanggung jawab dalam mengerjakan tugas, serta keterlibatan orang tua dalam mendampingi anak mengerjakan tugas.

Berdasarkan hasil wawancara kepada guru kelas 2 Sekolah Dasar Al Ikhwan, maka diperoleh data sebagai berikut:

Tabel 4. Hasil Wawancara

\begin{tabular}{ccl}
\hline No. & \multicolumn{1}{c}{ Aspek } & \multicolumn{1}{c}{ Hasil } \\
\hline 1. & Ketepatan Waktu & $\begin{array}{l}\text { Siswa X tidak selalu mengumpulkan tugas dengan } \\
\text { tepat waktu karena faktor keluarga. }\end{array}$ \\
& & $\begin{array}{l}\text { Siswa X tetap menyelesaikan dan mengumpulkan } \\
\text { tugas meski terkadang kurang maksimal. }\end{array}$ \\
& & Guru kelas memberikan nilai disesuaikan dengan \\
2. & Tanggung Jawab & \\
& &
\end{tabular}

Berdasarkan hasil wawancara kepada orang tua siswa $\mathrm{X}$, maka diperoleh data sebagai berikut:

Tabel 5. Hasil Wawancara

\begin{tabular}{cll}
\hline No. & \multicolumn{1}{c}{ Aspek } & \multicolumn{1}{c}{ Hasil } \\
\hline 1. & $\begin{array}{l}\text { Ketepatan } \\
\text { Waktu }\end{array}$ & $\begin{array}{l}\text { Siswa X terkadang mengumpulkan tugas di luar waktu yang } \\
\text { sudah ditentukan karena keterbatasan waktu yang dimiliki orang } \\
\text { tua. }\end{array}$ \\
2. & $\begin{array}{l}\text { Tanggung } \\
\text { Jawab }\end{array}$ & $\begin{array}{l}\text { Siswa X tetap berusaha mengerjakan tugas-tugas yang diberikan } \\
\text { oleh meskipun tidak mengumpulkan dengan tepat waktu. }\end{array}$
\end{tabular}




\section{PRIMARY: JURNAL PENDIDIKAN GURU SEKOLAH DASAR VOLUME 10 NOMOR 6 DESEMBER 2021 \\ ISSN : 2303-1514 | E-ISSN : 2598-5949 \\ DOI : http://dx.doi.org/10.33578/jpfkip.v10i6.8555 \\ https://primary.ejournal.unri.ac.id/index.php/JPFKIP}

Berdasarkan hasil wawancara kepada

siswa X, maka diperoleh data sebagai berikut:

Tabel 5. Hasil Wawancara

\begin{tabular}{|c|c|c|}
\hline No. & Aspek & Hasil \\
\hline 1. & Ketepatan Waktu & $\begin{array}{l}\text { Siswa X mengerjakan tugas berdasarkan waktu yang } \\
\text { dimiliki oleh orang tuanya sehingga tidak jarang } \\
\text { mengumpulkan tugas di luar batas waktu yang sudah } \\
\text { ditentukan. }\end{array}$ \\
\hline 2. & Tanggung Jawab & $\begin{array}{l}\text { Setelah mempelajari materi pelajaran, siswa X selalu } \\
\text { mengerjakan tugas yang diberikan oleh guru meskipun } \\
\text { tidak selalu dilakukan di hari yang sama saat guru } \\
\text { memberikan tugas dan menentukan batas waktu } \\
\text { pengumpulan tugas. }\end{array}$ \\
\hline 3. & Keterlibatan Orang Tua & $\begin{array}{l}\text { Orang tua siswa } X \text { selalu terlibat langsung dalam } \\
\text { membantu dan mendampingi siswa } X \text { mengerjakan } \\
\text { tugas-tugas sekolah miliknya. }\end{array}$ \\
\hline
\end{tabular}

Hasil yang diperoleh berdasarkan wawancara yang telah dilakukan kepada guru kelas, orang tua siswa, dan siswa yang ingin diteliti yaitu adalah bahwa siswa $\mathrm{X}$ tidak selalu mengumpulkan tugas yang telah diberikan oleh guru dengan tepat waktu. Misalnya jika setiap hari dalam seminggu guru tersebut memberikan tugas yang mengharuskan untuk memfotokan jawaban, maka siswa $\mathrm{X}$ akan mengumpulkan secara sekaligus di satu hari yang sama untuk keseluruhan tugas yang diberikan oleh guru tersebut. Hal tersebut dilakukan oleh orang tua siswa $\mathrm{X}$ berdasarkan komunikasi dan kesepakatan dengan guru kelas siswa X.

Faktor yang menyebabkan hal tersebut terjadi adalah faktor keluarga yang berkaitan dengan kesibukan yang dialami oleh kedua orang tua siswa $X$. Ayah dari siswa $X$ memiliki pekerjaan di luar kota tempat tinggal $X$, sedangkan Ibu dari siswa $X$ memiliki pekerjaan yang terkadang mengharuskan untuk melakukan dinas malam di Rumah Sakit. Sehingga tidak ada yang bisa mendampingi siswa $\mathrm{X}$ dalam belajar terutama saat mengerjakan tugas yang menyebabkan siswa $\mathrm{X}$ terkadang kerapkali mengumpulkan tugas berdasarkan waktu yang dimiliki oleh orang tuanya.

Namun meskipun tak jarang siswa $X$ mengumpulkan tugas di luar batas waktu yang telah di tentukan oleh guru kelasnya, siswa $\mathrm{X}$ tetap mengerjakan dan menyelesaikan seluruh tugas-tugas yang diberikan oleh guru kelasnya tersebut. Siswa $X$ dalam mengerjakan tugas biasanya dilakukan saat orang tuanya sudah menyelesaikan urusan pekerjaannya, atau jika orang tuanya sudah pulang dari kantor tempat orang tuanya bekerja, dan bahkan bisa juga saat orang tuanya mengambil cuti untuk membantu mendampingi siswa $\mathrm{X}$ mengerjakan tugas.

Dalam proses pengerjaan tugas siswa $X$ juga terdapat keterlibatan langsung yang dilakukan oleh orang tua siswa $\mathrm{X}$ khususnya oleh ibu siswa $X$, dikarenakan ayah siswa $X$ yang memiliki pekerjaan di luar kota tidak memiliki cukup waktu untuk terlibat langsung dalam proses pengerjaan tugas siswa $X$. Namun meskipun ibu dari siswa $\mathrm{X}$ memiliki 
kesibukan di tengah pekerjannya, ibu dari siswa $\mathrm{X}$ akan tetap berusaha meluangkan waktunya untuk mendampingi siswa $\mathrm{X}$ dalam belajar dan dalam pengerjaan tugas seperti membantu membantu menampilkan materi pembelajaran yang diberikan oleh guru kelasnya untuk dipelajari oleh siswa $\mathrm{X}$ sebelum mengerjakan tugas, membantu memfasilitasi media pembelajaran yang digunakan untuk mengerjakan tugas, membantu mengarahkan siswa $\mathrm{X}$ untuk mengerjakan tugas-tugas sesuai dengan perintah yang diminta oleh guru kelasnya, serta mendampingi siswa $\mathrm{X}$ saat sedang mengerjakan tugas-tugas sekolah miliknya.

\section{SIMPULAN DAN SARAN}

Berdasarkan hasil penelitian dan analisis data yang diperoleh dari hasil observasi dan wawacara kepada guru kelas, orang tua siswa, dan siswa yang ingin diteliti, serta dengan mengaitkan kajian teori yang sudah dipaparkan sebelumnya, maka dapat diperoleh kesimpulan bahwa terdapat siswa yang masih kurang memiliki sikap kedisiplinan dalam belajar terutama dalam aspek pengumpulan tugas. Hal tersebut disebabkan oleh kesibukan perkerjaan yang dialami orang tua dari siswa tersebut yang menyebabkan kurangnya keterlibatan orang tua dalam mendampingi anak belajar, sehingga siswa sering kali terlambat dalam mengumpulkan tugas yang sudah diberikan oleh guru.

Keterlibatan orang tua sangat diperlukan dalam mendampingi anak belajar terlebih saat proses pengerjaan tugas-tugas sekolah milik anak. Anak usia sekolah dasar khususnya kelas 2 sekolah dasar masih membutuhkan keterlibatan yang besar dari pihak orang tua dalam proses belajarnya. Hal tersebut juga berlaku saat proses pengerjaan dan pengumpulan tugas-tugas sekolah milik anak. Orang tua diharapkan bisa lebih memperhatikan proses belajar yang dialami oleh anak. Orang tua juga diharapkan untuk lebih bisa meluangkan waktunya untuk membantu serta mendampingi anak saat proses pembelajaran terlebih saat proses pengerjaan dan pengumpulan tugas anak. Karena keterlibatan orang tua dalam proses pembelajaran anak sangat penting dan memiliki dampak yang sangat besar yang berkaitan dengan aspek perkembangan perilaku anak.

Salah satu aspek perilaku anak dalam proses pembelajaran adalah aspek kedisiplinan belajar khususnya kedisiplinan anak sebagai siswa dalam mengumpulkan tugas. Kedisiplinan belajar anak memiliki beberapa faktor salah satunya yaitu faktor eksternal yang berasal dari lingkungan keluarga. Jika keluarga atau orang tua dari anak dapat terlibat secara langsung dalam proses pembelajaran anak seperti membantu dan mendampingi anak saat proses pengerjaan tugas, maka secara otomatis hal tersebut juga akan mempengaruhi keberhasilan proses pendidikan anak terutama dalam aspek kedisiplinan waktu pengumpulan tugas yang sesuai dengan batas waktu yang telah ditentukan oleh guru siswa tersebut.

\section{DAFTAR PUSTAKA}

Akmaluddin, \& Haqiqi, B. (2019). Kedisiplinan Belajar Siswa di Sekolah Dasar (SD) Negeri Cot Keu Eung Kabupaten Aceh Besar (Studi Kasus). Jurnal of Education Science (JES), 5(2), 1-12.

Ansel, M. F., \& Pawe, N. (2021). Pengaruh Bimbingan Belajar Orang Tua Terhadap Disiplin Belajar Siswa Sekolah Dasar. Ilmiah Kependidikan, 2, 301-312.

Arumingtyas, P. (2021). Peningkatan Kedisiplinan Belajar Peserta Didik Melalui Media Google Sites. Ilmiah Kependidikan, 9, 5-24.

Damsy et al. (2020). Peran Orang Tua dan Guru dalam Mengatasi Sikap dan Perilaku Menyimpang Anak. FKIP Universitas Tanjungpura, 1(1), 1-11.

Diadha, R. (2015). Keterlibatan Orang Tua Dalam Pendidikan Anak Usia Dini Di Taman Kanak-Kanak. Edusentris, 
ISSN : 2303-1514 | E-ISSN : 2598-5949

2(1),

61. https://doi.org/10.17509/edusentris.v $2 \mathrm{i} 1.161$

Efendi, D. (2020). Peran Orang Tua Dalam Pembelajaran Model Distance Learning Di Sekolah Dasar Kota Jayapura. Al-Madrasah: Jurnal Pendidikan Madrasah Ibtidaiyah, 5(1), 54. https://doi.org/10.35931/am.v5i1.400 Kaminudin Telaumbanua. (2018). Efektivitas Layanan Konseling Kelompok Dalam Meningkatkan Kedisiplinan Belajar Siswa Kelas Xi SMA Negeri 1 Lahusa. Jurnal Education, 4(1), 25-31.

Kristiyani, T. (2016). Keterlibatan Orangtua dalam Pendidikan dan Komitmen Siswa terhadap Sekolah: Studi Metaanalisis. Buletin Psikologi, 21(1), 31. https://doi.org/10.22146/bpsi.9844

Lestari, N. E. I., Murtono, \& Purbasari, I. (2021). Karakter Kedisiplinan Belajar Siswa Kelas V SDIT Hidayatullah di Desa Daren Selama di Rumah. 2(4), 1221-1228.

Puspitasari, H. M., \& Sutriyono. (2018).
Hubungan Kemandirian Belajar dan Kedisiplinan belajar Terhadap Prestasi Belajar Matematika. Jurnal Mitra Pendidikan, 2(1), 11-22.

Saftari, M., \& Fajriah, N. (2019). Penilaian Ranah Afektif Dalam Bentuk Penilaian Skala Sikap Untuk Menilai Hasil Belajar. Edutainment, 7(1), 7181.

https://doi.org/10.35438/e.v7i1.164

Sopiah, C. (2020). Karakter kedisiplinan. Jurnal Jendela Bunda, 7(2), 34-44.

Sugiarto, A. P., Suyati, T., \& Yulianti, P. D. (2019). Faktor Kedisiplinan Belajar Pada Siswa Kelas X Smk Larenda Brebes. Mimbar Ilmu, 24(2), 232. https://doi.org/10.23887/mi.v24i2.21 279

Yulianingsih, W., Suhanadji, S., Nugroho, R., \& Mustakim, M. (2020). Keterlibatan Orangtua dalam Pendampingan Belajar Anak selama Masa Pandemi Covid-19. Jurnal Obsesi: Jurnal Pendidikan Anak Usia Dini, 5(2), 1138-1150. https://doi.org/10.31004/obsesi.v5i2. 740 